\title{
Menciptakan Nilai Untuk Nasabah Dengan Strategi Customer Relationship Marketing
}

\author{
RONI ANDESPA \\ Sekolah Tinggi Ilmu Ekonomi Riau (STIER) \\ Jln. HR. Subrantas 57 Panam Pekanbaru 28293 Telp. (0761) 63237 \\ E-mail : akbar_stier@yahoo.com
}

\begin{abstract}
This study is located in the city of Pekanbaru, in order to see the effect of customer relationship marketing variables on the variable banking customer value. With a sample of clients is 300. The results showed significant values among the variables of customer relationship marketing on customer value variables simultaneously is sig. $0,000(<0,05)$. This shows a significant difference between the independent variables on the dependent variables simultaneously study. Significant value to the customer relationship marketing variable variable value shows the value of a partial client $<0.05$, where it showed a significant difference between the independent variable on the dependent variable partial research. Customer relationship marketing variables could explain the variable customer value by $54.4 \%$, while the remaining $45.6 \%$ are influenced by variables or factors that exist outside of research. Where the value of $\mathrm{R}=0.738$ means a strong contribution value of the variable customer relationship marketing to customer value that is equal to $73.8 \%$.
\end{abstract}

Keywords: Customer, relationship, marketing, value, bank

Banyak ragam cara, strategi, dan kebijakan yang dapat dilakukan oleh perusahaanperusahaan yang bergerak di sektor perbankan untuk tetap bertahan hidup (survive) dan agar tetap bisa menjaga eksistensi usahanya, dan disamping itu perusahaan-perusahaan perbankan tersebut juga harus menghadapi persaingan yang sangat ketat antara sesama perbankan ataupun lembaga-lembaga keuangan lainnya yang menghadirkan produk jasa yang sama dengan sektor perbankan.

Salah satu cara yang dapat ditempuh oleh perusahaan perbankan dalam hal ini adalah dengan cara menentukan strategi yang tepat dan jitu agar tetap bisa bertahan di tengah persaingan serta mampu meningkatkan keuntungannya.

Didalam menerapkan dan melaksana kan strategi untuk meningkatkan keunggulan dalam bersaing, pihak perbankan akan mengalami kesulitan jika tanpa adanya dukungan dari pihak internal perusahaan maupun pihak luar perusahaan yang dalam hal ini adalah para nasabah yang selalu menuntut kepuasan atas kinerja dari perusahaan perbankan (Prichard et al, 1999).

Didalam situasi persaingan yang sangat ketat tersebut, yang akan menjadi prioritas utama bagi perusahaan-perusahaan perbankan adalah memberikan kepuasan bagi nasabah (customer satisfaction), sehingga bank tersebut dapat bertahan hidup, bersaing dan menguasai pangsa pasar perbankan.

Keberhasilan pemasaran suatu produk jasa perbankan tidak cukup hanya dengan menawarkan berbagai keunggulan yang dimiliki oleh jasa tersebut, justru yang paling penting adalah apakah pemberian jasa perbankan tersebut sudah sesuai dengan keinginan atau harapan dan dapat memenuhi kebutuhan nasabah tersebut, sehingga dapat meningkatkan nilai bagi nasabah (customer value).

Untuk menciptakan loyalitas nasabah, maka perusahaan perbankan harus dapat meningkatkan nilai bagi nasabahnya (customer value). Nilai nasabah bisa diciptakan melalui kualitas pelayanan (service quality) yang diberikan oleh perusahaan kepada para pelanggannya. Semakin baik kualitas pelayanannya, akan semakin tinggi pula nilai pelanggan terhadap perusahaan tersebut. 
Tingginya kualitas pelayanan juga tidak akan lepas dari dukungan internal yang ada di dalam perusahaan perbankan, terutama dukungan dari sumber daya manusia yang dimiliki oleh perusahaan perbankan tersebut apakah memadai atau tidak. Agar strategi pemasaran perbankan bisa berhasil diterapkan, maka pihak perusahaan perbankan harus mampu melaksanakan suatu hubungan pemasaran dengan nasabah yang telah dimilikinya (customer relationship marketing) secara baik dan berkelanjutan.

Customer Relationship marketing merujuk kepada semua aktivitas pemasaran yang diarahkan kepada pembentukan, pengembangan, dan pemeliharaan keberhasilan hubungan antara perusahaan dengan pelanggan yang dimilikinya (Too et al, 2000).

Maka dari pada itu agar perusahaan dapat berhasil di tengah persaingan yang ketat, maka perusahaan harus melakukan strategi yang tepat dalam memasarkan produknya. Strategi pemasaran tersebut dapat berhasil hanya dengan melakukan hubungan pemasaran dengan nasabah (customer relationship marketing) yaitu strategi pemasaran yang melibatkan perusahaan dan pelanggan.

Rangsangan yang ingin dibangkitkan dari konsep customer relationship marketing adalah metode-metode didalam menarik perhatian, pemeliharaan kepuasan nasabah serta meningkatkan dan mempererat hubungan kepuasan dengan pelanggan. Dengan kata lain, customer relationship marketing berupaya memperpanjang umur waktu hidup nasabah. (Khoe Yaou Tung, 1997).

Hasil yang dapat diperoleh dari customer relationship marketing adalah suatu proses pembentukan dan keterkaitan didalam memanejemen kolaborasi dengan pelanggan, membangun hubungan mata rantai untuk meningkatkan nilai pelanggan (customer value), dan mencapai kemampulabaan.

Customer relationship marketing berusaha membangun hubungan dan perhatian yang lebih kontruktif dengan pelanggan terpilih dan terseleksi, terlebih penting didalam memperluas kesuksesan pemasaran jangka panjang dibandingkan hanya mengejar target pengumpulan perhatian publik dalam skala yang lebih luas (Khoe Yaou Tung, 1997).

Dalam konteks perbankan, pertumbuhan pasar yang lambat dan tekanan persaingan yang intensif mengharuskan perusahaan mampu mempertahankan pelanggan yang sudah ada (Sirohi et. al. 1998: 230). Pentingnya memelihara pelanggan lebih dikarenakan kenyataan bahwa memperoleh atau mendapatkan pelanggan baru membutuhkan biaya yang lebih mahal daripada mempertahankan pelanggan (Stone et. al. 1996: 676).

Maka, dari pada itu memahami bagaimana atau mengapa suatu perasaan loyalitas perlu dikembangkan dalam benak pelanggan merupakan isu manajemen saat ini (Pritchard et. al. 1999: 333).

Customer relationship marketing dapat memberikan manfaat bagi nasabah perbankan, dan memungkinkan untuk menghambat persaingan dari pesaing yang ada, sehingga membuat perusahaan mampu untuk meningkatkan kepuasan pelanggan. Dalam kondisi persaingan yang sangat ketat, hal utama yang harus diprioritaskan perusahaan perbankan adalah kepuasan nasabah (customer satisfaction) yang pada akhirnya akan meningkatkan loyalitas pelanggan (customer loyality) sehingga perusahaan dapat bertahan, bersaing dan menguasai pangsa pasar.

Pritchard et al (1999) menyatakan bahwa loyalitas pelanggan terhadap merek (brand loyality) dipengaruhi langsung oleh kepuasan pelanggan pada merek yang diakumulasikan melalui waktu.

Apabila pelanggan merasa puas akan mendukung keberhasilan pemasaran perusahaan. Sedangkan perusahaan itu sendiri dapat membentuk kepuasan dengan menciptakan nilai pelanggan (customer value) dan keunggulan produk (product advantages).

Sektor perbankan di kota Pekanbaru memiliki pertumbuhan yang cukup signifikan dalam beberapa tahun terakhir ini. Hal ini mengindikasikan adanya peningkatan kinerja sektor perbankan yang signifikan dikota ini dan makin besarnya potensi bisnis yang ada. Namun disisi lainnya juga munculnya persaingan sesama perusahaan perbankan, disi- 
nilah pentingnya menciptakan nilai bagi nasabah untuk memenangkan persaingan antara sesama perbankan di kota Pekanbaru.

\section{Pemasaran}

Pemasaran dan produksi merupakan fungsi pokok bagi perusahaan semua berusaha memproduksi dan memasarkan produk atau jasa untuk memenuhi kebutuhan konsumen. Pada saat ini kegiatan pemasaran mempunyai peranan penting dalam dunia usaha, istilah pemasaran ini diartikan sama dengan beberapa istilah, seperti: penjualan, perdagangan, dan distribusi. Pemasaran merupakan konsep yang sangat menyeluruh sedangkan istilah yang lain tersebut hanya merupakan satu bagian, satu kegiatan dalam sistem pemasaran secara keseluruhan. Secara definitif pemasaran adalah sebagai berikut:

Pengertian pemasaran menurut William J. Stanton (1978) Pemasaran adalah sistem keseluruhan dari kegiatan-kegiatan bisnis yang ditunjukan untuk merencanakan, menetukan harga, mempromosikan, dan mendistribusikan barang dan jasa yang dapat memuaskan kebutuhan kepada pembeli yang ada maupun pembeli potensial.

Sedangkan pengertian pemasaran menurut Kotler dan Armstrong (1997) pemasaran adalah suatu proses sosial dan manajerial yang membuat individu dan kelompok apa yang mereka butuhkan serta inginkan lewat penciptaan dan pertukaran timbal balik produk dan nilai dengan orang lain.

Dari definisi diatas dapat diambil kesimpulan bahwa pada dasarnya kegiatan pemasaran meliputi:

a. Menentukan produk yang dibutuhkan oleh konsumen.

b. Merencanakan dan mengembangkan produksi, baik berupa barang atau jasa yang dapat memuaskan kebutuhan konsumen.

c. Menentukan harga, promosi dan distribusi

d. Mencari input dari konsumen maupun lembaga pemasaran untuk kebijaksanaan selanjutnya.

Jadi pemasaran merupakan suatu interaksi yang berusaha untuk menciptakan hubungan pertukaran yang ditujukan untuk memberikan kepuasan baik penjual maupun pem- beli.

\section{Konsep Pemasaran}

Konsep pemasaran merupakan
falsafah penting didalam perusahaan perbankan yang menyatakan keinginan pembeli didalam ini adalah nasabah dan adalah merupakan syarat utama bagi kelangsungan hidup perusahaan perbankan. Konsep pemasaran berorientasi pada kebutuhan dan keinginan nasabah yang didukung oleh pemasaran yang diarahkan kepada terciptanya kepuasan bagi nasabah sektor perbankan. Secara definitif konsep pemasaran adalah sebagai berikut: konsep pemasaran adalah sebuah falsafah bisnis yang menyatakan bahwa pemuasan kebutuhan konsumen merupakan syarat ekonomi dan sosial bagi kelangsungan hidup perusahaan (Swastha dan Irawan, 1997).

Sedangkan konsep pemasaran menurut Philip Kotler adalah sebagai berikut, konsep pemasaran adalah kunci untuk meraih tujuan organisasi agar menjadi efektif dari pada para pesaing dalam memadukan kegiatan pemasaran guna menetapkan dan memuaskan (Kotler, 1997). Konsep pemasaran tersebut disusun dengan memasukkan tiga elemen pokok yaitu:

1) Orientasi konsumen/pasar/pembeli

Pada dasarnya perusahaan yang ingin menerapkan orientasi konsumen ini harus:

a. Menentukan kebutuhan pokok dari pembeli yang akan dilayani dan dipenuhi.

b. Memilih kelompok pembeli tertentu sebagai sasaran dalam penjualanya.

c. Menentukan produk dan program pemasaranya.

d. Mengadakan penelitian kepada konsumen, untuk mengukur, menilai dan menafsirkan keinginan, sikap, serta tingkah laku mereka.

e. Menentukan dan melaksanakan strategi yang paling baik, apakah menitik beratkan pada mutu yang tinggi, harga yang murah atau model yang menarik. 
2) Volume penjualan yang menguntungkan

Penjualan yang menguntungkan merupakan tujuan dari konsep pemasaran, artinya laba dapat diperoleh dengan melalui pemasaran konsumen. Dengan laba ini perusahaan dapat tumbuh dan berkembang dapat menggunakan kemampuan yang lebih besar pada konsumen, serta dapat memperkuat kondisi perekonomian secara keseluruhan.

\section{Customer Relationship Marketing}

Customer Relationship marketing merupakan konsep baru yang muncul dalam literature pemasaran pada beberapa dekade terakhir (Christopher et. al. 1991; Gronroos, 1994; Gummeson, 1994; Morgan dan Hunt, 1994; Benet, 1996). Istilah "customer relationship marketing" penggunaannya sudah meluas (Evans dan Laskin, 1994; dan Gronroos, 1990).

Dalam konteks ini, banyak definisi customer relationship marketing ditulis dalam bentuk output yang diinginkan, dan tidak mengindikasikan kebutuhan input atau ciri-ciri yang mana memungkinkan pengamat menentukan bila sebuah kebijakan customer relationship marketing dilaksanakan (Blois, 1996, p.161).

Customer relationship marketing merupakan sebuah bentuk pemasaran dimana perusahaan mempunyai target dalam nasabah dan membuat komunikasi pemasaran yang relevan. Proses dalam customer relationship marketing antara lain (Hughes, 1999, p.1):

1. Menciptakan informasi nasabah

2. Menghitung keuntungan dari adanya nasabah

3. Membagi nasabah berdasarkan keuntungan

4. Mengatur nasabah

5. Menghitung nilai manfaat dan keuntungan yang potensial

Customer relationship marketing berfokus pada membangun hubungan dengan pelanggan satu demi satu. Hal ini dibutuhkan pengetahuan yang mendalam dan akurat dalam situasi, perilaku, kebutuhan dan prefensi nasabah. Studi mengenai hubungan pemasaran nasabah (customer relationship marketing) penuh dengan anteseden, hasil, serta aktifitas hubungan pemasaran itu sendiri. Sebagai con- toh, Morgan dan Hunt (1994, p.22) mengemukakan bahwa banyak referensi definisi hubungan pemasaran nasabah (customer relationship marketing) menawarkan semua aktifitas pemasaran mulai dari pendirian, pengembangan, dan pemeliharaan. Definisi ini berangkat dari tujuan pokok dari customer relationship marketing.

Lebih jauh ditemukan bagaimana cara mengimplementasikan konsep customer relationship marketing atau kebutuhan apa dalam implementasi customer relationship marketing. Ada beberapa ukuran customer relationship marketing (Gronroos, 1990) yaitu:

1. Fokus nasabah jangka panjang

2. Membuat komunikasi dengan nasabah

3. Melibatkan anggota organisasi didalam aktivitas pemasaran

4. Implementasi proses interaktif pemasaran

5. Mengembangkan budaya pelayanan untuk nasabah

6. Memperoleh dan menggunakan informasi nasabah

Ada kesamaan antara beberapa ukuran customer relationship marketing dengan prinsip dalam konsep pemasaran (Kohli dan Jaworski, 1990; Narver dan Slater, 1990; Cadogan dan Diamantopoulos, 1995).

Dalam konteks ini, konsep customer relationship marketing dapat dikatakan sebagai sebuah filosofi manajemen (Bennett, 1996) yang mencakup konsep pemasaran dan hubungan jangka panjang dengan pelanggan dalam transaksi yang menguntungkan (Palmer, 1994). Sebuah orientasi customer relationship marketing (Gronroos, 1990), dengan tujuan untuk mengembangkan dan memelihara hubungan pemasaran dengan pelanggan di dalam orientasi pasar.

\section{Nilai Nasabah (Customer Value)}

Konsep nilai nasabah memberikan gambaran tentang nasabah suatu perusahaan, mempertimbangkan apa yang mereka inginkan, dan percaya bahwa 
mereka memperoleh manfaat dari suatu produk (Woodruff, 1997). William A. Band (1991) melihat perlunya lintas fungsional dalam sebuah perusahaan, yaitu pemasaran, operasi dan sumber daya manusia sebagai prasyarat dalam mengelola nilai nasabah. Elemen mengelola hubungan dengan pelanggan dan mengelola persepsi nilai adalah tugas dari fungsi pemasaran, elemen meningkatkan kemampuan para karyawan sebagai value creator adalah tugas dari manajemen sumber daya manusia, sedangkan elemen meningkatkan kinerja kualitas adalah tugas dari fungsi operasi (Sinkula et al, 1997).

Dari beberapa hasil penelitian yang telah dilakukan oleh beberapa peneliti diperoleh definisi tentang nilai nasabah. Nilai pelanggan merupakan keseluruhan penilaian pelanggan tentang kegunaan suatu produk yang berdasar pada persepsi tentang apa yang diterima dan apa yang diberikan (Zeithami, 1987). Persepsi pembeli tentang nilai yang menggambarkan sebuah perbandingan antara kualitas atau keuntungan yang mereka rasakan dalam produk dengan pengorbanan yang mereka rasakan ketika membayar harga produk.

Nilai nasabah merupakan kualitas yang dirasakan nasabah yang disesuaikan dengan harga relatif dari produk yang dihasilkan oleh suatu perusahaan (Slater dan Narver, 1994, p.23). Dengan nilai pelanggan atau konsumen, kita mengartikan ikatan emosional yang terbentuk antara konsumen dan produsen setelah konsumen menggunakan suatu produk atau jasa penting yang diproduksi oleh produsen dan menemukan produk tersebut memberikan suatu tambahan nilai (Butz dan Goodstein, 1996).

Ada dua metode bagi perusahaan untuk menyamakan persepsinya tentang nilai dengan nasabah (Woodruff, 1997) yaitu:

\section{Informal Research Learning}

Yang dimaksud adalah pengalamanpengalaman dari masa lalu yang didapat dari trial and error, umpan balik yang berasal dari interaksi nasabah dengan tenaga penjual (salesman), dan observasi langsung dari pihak manajer kepada nasabahnya.

\section{Formal Research Learning}

Metode ini berisi semua variasi pasar dan riset terhadap perilaku konsumen terhadap perusahaan. Didalam metode ini, perusahaan mendapatkan informasi dari eksperimen-eksperimen, survei dan riset kualitatif. Dengan adanya penyamaan persepsi antara perusahaan dengan nasabah tersebut maka diharapkan akan terbentuk suatu nilai nasabah yang superior. Setelah nilai tersebut terbentuk, maka nilai tersebut perlu disampaikan kepada nasabah.

Untuk dapat mencapai hasil yang optimal maka diperlukan sistem nilai bagi nasabah, yaitu sistem yang terdiri dari rantai nilai dari perusahaan dan pemasok, dan akhirnya mereka yang bekerja sama untuk menyampaikan nilai kepada nasabah (Kotler and Armstrong, 1997; Woodruff, 1997).

Konsep nilai nasabah mengindikasi kan suatu hubungan yang kuat terhadap kepuasan konsumen atau nasabah (Woodruff, 1997). Dimana konsep tersebut menggambarkan pertimbangan yang evaluatif pelanggan tentang produk yang mereka konsumsi. Nilai yang diinginkan nasabah terbentuk ketika mereka membentuk persepsi bagaimana baik buruknya suatu produk dimainkan dalam situasi penggunaan. Mereka mengevaluasi pengalaman penggunaan pada atribut yang sama, seperti telah dijelaskan diatas bahwa atribut yang dimaksud disini adalah merk dan kualitas pelayanan atas produk.

Nilai yang diterima bisa dijadikan untuk mengarahkan secara langsung pada formasi perasaan-perasaan kepuasan nasabah secara keseluruhan. Kepuasan secara menyeluruh merupakan perasaanperasaan nasabah dalam respon untuk evaluasi dari satu atau lebih pengalaman konsumen dalam penggunaan suatu produk. Dengan tercapainya tingkat kepuasan yang diperoleh oleh nasabah yang optimal maka mendorong terciptanya loyalitas di benak nasabah yang merasa puas tadi terhadap perusahaan perbankan.

\section{Dimensi Customer Relationship Marketing}

Pada variabel customer relationship marketing terdapat atau dibentuk oleh lima 
dimensi yaitu (Gronroos, 1990).

1. Fokus pelanggan jangka panjang.

2. Menjalin komunikasi yang baik dengan nasabah.

3. Melibatkan organisasi-anggota dalam aktivitas pemasaran.

4. Mengembangkan budaya pelayanan untuk nasabah.

5. Memperoleh dan menggunakan informasi nasabah

\section{Pengaruh Customer Relationship Marketing Terhadap Nilai Nasabah}

Customer relationship marketing merupakan sebuah bentuk pemasaran dimana perusahaan mempunyai target dalam nasabah dan membuat komunikasi pemasaran yang relevan. Sedangkan nilai nasabah merupakan ikatan emosional yang terbentuk antara konsumen dan produsen setelah konsumen menggunakan suatu produk atau jasa yang diproduksi oleh produsen dan menemukan produk tersebut memberikan suatu gambaran nilai (Butz Goodstein, 1996).

Untuk dapat mencapai hasil yang optimal maka diperlukan system nilai bagi nasabah, yaitu system yang terdiri dari rantai nilai dari perusahaan untuk menyampaikan nilai kepada nasabah (Kotler, 1997). Dalam menyampaikan nilai kepada nasabah diperlukan adanya hubungan pemasaran nasabah (customer rekationship marketing) yang berfokus pada pelanggan dalam jangka panjang (Gronroos, 1990).

Hipotesis didalam penelitian adalah sebagai berikut:

$\mathrm{H}_{1}=$ Diduga variabel customer relationship marketing secara simultan berpengaruh secara signifikan terhadap variabel nilai nasabah.

$\mathrm{H}_{2}=$ Diduga variabel customer relationship marketing secara parsial berpengaruh secara signifikan terhadap variabel nilai nasabah.

\section{METODE}

Populasi yang digunakan adalah seluruh nasabah perbankan di kota Pekanbaru, Riau. Dimana sampel dalam penelitian yang digunakan adalah sebanyak 300 nasabah. Teknik pengambilan sampel yang digunakan adalah metode non probability sampling dengan Convenience sampling, mengingat dimana jumlah populasi yang cukup besar, maka setiap nasabah yang mudah untuk ditemui, dan rasanya bisa untuk menjadi sampel, maka berhak untuk menjadi responden. Hal ini dilakukan untuk diagnosis situasi secara cepat dan bersifat sederhana serta mudah, karena adanya keterbatasan waktu didalam penelitian. Data yang digunakan adalah data primer yang diperoleh melalui penyebaran kuesioner kepada responden yang dijadikan sampel dengan pertanyaan tertutup dimana skala pengukurannya menggunakan skala 1 sampai dengan 5 (skala likert). Dimana angka 1 mewakili Sangat Tidak Setuju (STS) sampai dengan angka 5 mewakili Sangat Setuju (SS). Analisis data dilakukan dengan menggunakan regresi linier berganda.

\section{HASIL}

Setelah data dengan menggunakan metode kuesioner terkumpul, maka dilakukan pengolahan data dengan bantuan komputer, dan didapat outputnya sebagai berikut:

Tabel 1. Output SPSS Model Summary Variabel Customer relationship marketing Terhadap Nilai Nasabah

\begin{tabular}{|l|r|r|r|r|}
\hline Model & \multicolumn{1}{|c|}{ Model Summary } \\
\hline 1 &, $738^{\mathrm{a}}$ &, 544 & \multicolumn{1}{|c|}{$\begin{array}{c}\text { Adjusted R } \\
\text { Square }\end{array}$} & $\begin{array}{c}\text { Std. Error of } \\
\text { the Estimate }\end{array}$ \\
\hline
\end{tabular}

a. Predictors: (Constant), Memperoleh dan menggunakan informasi nasabah, Melibatkan organisasi-anggota dalam aktivitas pemasaran, Menjalin komunikasi yang baik dengan nasabah, Mengembangkan budaya pelayanan untuk nasabah, Fokus pelanggan jangka panjang Sumber: Data Primer, Olahan SPSS

Dari tabel Model Summary dapat dilihat nilai $\mathrm{R}$ Square menunjukkan variabel-variabel customer relationship marketing mampu menjelaskan variabel nilai nasabah sebesar 54,4\%, sedangkan sisanya sebesar $45,6 \%$ dipengaruhi oleh variabel atau faktor di luar penelitian. Dimana nilai $\mathrm{R}=0,738$ artinya merupakan nilai kontribusi yang kuat dari variabel customer relationship marketing terhadap nilai nasabah yaitu sebesar $73,8 \%$. 
Tabel 2. Output SPSS Anova Variabel Customer relationship marketing Terhadap Nilai Nasabah ANOVAa

\begin{tabular}{|c|c|c|c|c|c|c|}
\hline \multicolumn{2}{|c|}{ Model } & Sum of Squares & $d f$ & Mean Square & $\mathrm{F}$ & Sig. \\
\hline \multirow{3}{*}{1} & Regression & 59,495 & 5 & 11,899 & 70,251 &, 000 \\
\hline & Residual & 49,797 & 294 & 169 & & \\
\hline & Total & 109,292 & 299 & & & \\
\hline
\end{tabular}

a. DependentVariable: Nilai Nasabah

b. Predictors: (Constant), Memperoleh dan menggunakan informasi nasabah, Melibatkan organisasi-anggota dalam aktivitas pemasaran, Menjalin komunikasi yang baik dengan nasabah, Mengembangkan budaya pelayanan untuk nasabah, Fokus pelanggan jangka panjang

Sumber: Data Primer, Olahan SPSS

Dari hasil output pengolahan dengan komputer yang pada tabel 2 dapat dilihat nilai signifikansi variabel-variabel customer relationship marketing terhadap nilai nasabah secara simultan menunjukan nilai sig. $0,000(<0,05)$ pada tingkat $\alpha=5 \%$. Hal ini menunjukan bahwa terdapat pengaruh yang signifikan antara variabel independent terhadap variabel dependent penelitian. Maka hipotesis 1 dalam penelitian, "Diduga variabel-variabel customer relationship marketing secara simultan berpengaruh signifikan terhadap variabel nilai nasabah", diterima di dalam penelitian.

Tabel 3. Output SPSS Coefficients Variabel Customer relationship marketing Terhadap Nilai Nasabah

\begin{tabular}{|c|c|c|c|c|c|}
\hline \multirow[t]{2}{*}{ Model } & \multicolumn{2}{|c|}{ Unstandardized Coefficients } & \multirow{2}{*}{$\begin{array}{c}\text { Standardized } \\
\text { Coefficients } \\
\text { Beta } \\
\end{array}$} & \multirow[t]{2}{*}{$\mathrm{t}$} & \multirow[t]{2}{*}{ Sig. } \\
\hline & B & Std. Error & & & \\
\hline \multirow{6}{*}{$\begin{array}{l}\text { (Constant) } \\
\text { Fokus pelanggan jangka } \\
\text { panjang } \\
\text { Menjalin komunikasi yang } \\
\text { baik dengan nasabah } \\
\text { Melibatkan organisasi- } \\
\text { anggota dalam aktivitas } \\
\text { pemasaran } \\
\text { Mengembangkan budaya } \\
\text { pelayanan untuk nasabah } \\
\text { Memperoleh dan } \\
\text { menggunakan informasi } \\
\text { nasabah }\end{array}$} & ,791 & ,170 & & 4,666 & 000 \\
\hline & , 118 &, 026 & ,185 & 4,538 &, 000 \\
\hline & , 165 &, 026 & ,254 & 6,353 &, 000 \\
\hline & ,212 & 027 & ,318 & 7,803 &, 000 \\
\hline & ,219 & ,028 &, 321 & 7,896 &, 000 \\
\hline & ,187 &, 028 &, 275 & 6,776 &, 000 \\
\hline
\end{tabular}

a. Dependent Variable: Nilai Nasabah

Sumber: Data Primer, Olahan SPSS

Pada tabel Coefficients diatas yang merupakan hasil pengolahan komputer menunjukan pengaruh variabel-variabel customer relationship marketing terhadap nilai nasabah secara parsial, dapat terlihat:

Pada bagian variabel fokus pelanggan jangka panjang terhadap variabel nilai nasabah terlihat nilai signifikannya adalah sig. 0,000 $(<0,05)$, dimana hal menunjukan pengaruh yang signifikan antara variabel fokus pelanggan jangka panjang terhadap varibel nilai nasabah konsumen.

Pada variabel menjalin komunikasi yang baik dengan nasabah terhadap variabel nilai nasabah dengan nilai signifikannya adalah sig. 0,000 $(<0,05)$, dimana hal menunjukan pengaruh yang signifikan antara variabel menjalin komunikasi yang baik dengan nasabah terhadap variabel nilai nasabah.

Pada variabel melibatkan organisasi anggota dalam aktivitas pemasaran terhadap variabel nilai nasabah, terlihat dengan nilai signifikannya adalah sig. $0,000(<0,05)$, dimana menunjukan pengaruh yang signifikan antara variabel melibatkan organisasi anggota dalam aktivitas pemasaran terhadap variabel nilai nasabah.

Pada variabel mengembangkan budaya pelayanan untuk nasabah terhadap variabel nilai nasabah nilai signifikannya adalah sig. 0,000 $(<0,05)$, dimana terlihat menunjukan pengaruh yang signifikan antara variabel mengembangkan budaya pelayanan terhadap variabel nilai nasabah.

Pada variabel memperoleh dan menggunakan informasi nasabah terhadap variabel nilai nasabah nilai signifikannya adalah sig. 0,000 $(<0,05)$, dimana menunjukkan pengaruh yang signifikan antara variabel memperoleh dan menggunakan informasi nasabah terhadap variabel nilai nasabah.

Maka hipotesis 2 "Diduga variabel customer relationship marketing mempengaruhi nilai nasabah secara parsial". Diterima didalam hasil penelitian ini.

Dari tabel 3 juga bisa dilihat bahwa terlihat konstanta $(\alpha)$ sebesar 0,791, koefisien $\left(\beta_{1}\right)$ sebesar 0,118 , koefisien $\left(\beta_{2}\right)$ sebesar 0,165 , koefisien $\left(\beta_{3}\right)$ sebesar 0,212 , koefisien $\left(\beta_{4}\right)$ sebesar 0,219 , dan $\left(\beta_{5}\right)$ sebesar 0,187 sehingga hasil tersebut dapat ditampilkan kedalam bentuk persamaan sebagai berikut:

$Y=\alpha+\beta_{1} X_{1}+\beta_{2} X_{2}+\beta_{3} X_{3}+\beta_{4} X_{4}+\beta 5 X_{5}$ 
Jika diasumsikan dapat ditulis persamaannya sebagai berikut:

$$
\mathrm{Y}=0,791+0,118+0,165+0,212+0,219+0,187
$$

Pada persamaan di atas dapat diartikan bahwa besarnya pengaruh fokus pelanggan jangka panjang $\left(\mathrm{X}_{1}\right)$ terhadap nilai nasabah $(\mathrm{Y})$ sebesar 0,118, ini berarti apabila variabel fokus pelanggan jangka panjang ditingkatkan sebesar satu satuan variabel, maka variabel nilai nasabah akan meningkat sebesar 0,118 kali satuan variabel, dengan syarat variabel $\mathrm{X}_{2}$, $\mathrm{X}_{3}, \mathrm{X}_{4}$ dan $\mathrm{X}_{5}$ tetap, dan apabila variabel fokus pelanggan jangka panjang nol (tetap), maka variabel nilai nasabah tetap ada sebesar konstanta 0,791.

Dari persamaan diatas dapat diartikan bahwa besarnya pengaruh menjalin komunikasi yang baik dengan nasabah $\left(\mathrm{X}_{2}\right)$ terhadap nilai nasabah (Y) sebesar 0,165 , ini berarti apabila variabel menjalin komunikasi yang baik dengan nasabah ditingkatkan sebesar satu satuan variabel, maka variabel nilai nasabah akan meningkat sebesar 0,165 kali satuan variabel, dengan syarat variabel $\mathrm{X}_{1}, \mathrm{X}_{3}, \mathrm{X}_{4}$ dan $\mathrm{X}_{5}$ tetap, dan apabila variabel menjalin komunikasi yang baik dengan nasabah dimisalkan nol (tetap), maka variabel nilai nasabah tetap ada sebesar konstanta 0,791 .

Dari persamaan diatas dapat diartikan bahwa besarnya pengaruh melibatkan organisasi/anggota didalam aktifitas pemasaran $\left(\mathrm{X}_{3}\right)$ terhadap nilai nasabah $(\mathrm{Y})$ sebesar 0,212 , ini berarti apabila variabel melibatkan organisasi/anggota didalam aktifitas pemasaran ditingkatkan sebesar satu satuan variabel, maka variabel nilai nasabah akan meningkat sebesar 0,212 kali satuan variabel, dengan syarat variabel $\mathrm{X}_{1}, \mathrm{X}_{2}, \mathrm{X}_{4}$ dan $\mathrm{X}_{5}$ tetap, dan apabila variabel melibatkan organisasi/anggota didalam aktifitas pemasaran dimisalkan nol (tetap), maka variabel nilai nasabah tetap ada sebesar konstanta 0,791 .

Dari persamaan diatas dapat diartikan bahwa besarnya pengaruh mengembangkan budaya pelayanan untuk nasabah $\left(\mathrm{X}_{4}\right)$ terhadap nilai nasabah (Y) sebesar 0,219 , ini berarti apabila variabel mengembangkan budaya pelayanan untuk nasabah ditingkatkan sebesar satu satuan variabel, maka variabel nilai nasabah akan meningkat sebesar 0,219 kali satuan variabel, dengan syarat variabel $X_{1}, X_{2}, X_{3}$ dan $\mathrm{X}_{5}$ tetap, dan apabila variabel mengembangkan budaya pelayanan untuk nasabah dimisalkan nol (tetap), maka variabel nilai nasabah tetap ada sebesar konstanta 0,791.

Dari persamaan diatas dapat diartikan bahwa besarnya pengaruh memperoleh dan menggunakan informasi nasabah $\left(\mathrm{X}_{5}\right)$ terhadap nilai nasabah sebesar (Y) 0,187, ini berarti apabila variabel memperoleh dan menggunakan informasi nasabah ditingkatkan sebesar satu satuan variabel, maka variabel nilai nasabah akan meningkat sebesar 0,187 kali satuan variabel, dengan syarat variabel $X_{1}, X_{2}, X_{3}$ dan $\mathrm{X}_{4}$ tetap, dan apabila variabel memperoleh dan menggunakan informasi nasabah dimisalkan nol (tetap), maka variabel nilai nasabah tetap ada sebesar konstanta 0,791 .

\section{PEMBAHASAN}

Berdasarkan hasil analisis dan pengujian hipotesis yang telah dikemu kakan sebelumnya, maka dapat dibuat pembahasan secara teoritis ataupun praktisnya, adalah sebagai berikut dibawah ini.

\section{Implikasi Teoritis}

Di dalam penelitian ini customer relationship marketing dibentuk oleh lima variabel/dimensi yaitu fokus pelanggan jangka panjang, menjalin komunikasi yang baik dengan nasabah, melibatkan organisasi-anggota dalam aktivitas pemasaran, mengembangkan budaya pelayanan untuk nasabah, dan memperoleh dan menggunakan informasi nasabah, memberikan pengaruh yang kuat terhadap nilai nasabah dan keunggulan produk dimana semakin tinggi customer relationship marketing maka akan semakin tinggi pula nilai nasabah dan keunggulan produk.

Dimana kesimpulan yang diperoleh dari hasil penelitian ini searah dengan kesimpulan penelitian yang telah dilakukan oleh Gronroos, (1990), Butz Goodstein, (1996) Too, Souchon dan Thirkell (2000) dan Leo YM Sin et al (2002). 


\section{Implikasi Praktis}

Dari hasil penelitian terlihat bahwa variabel-varibel customer relationship marketing mempunyai pengaruh yang positif terhadap variabel nilai nasabah yang ada di kota Pekanbaru baik itu secara simultan maupun secara parsial. Dimana nilai nasabah dapat ditingkatkan melalui customer relationship marketing melalui lima dimensi yaitu, fokus pelanggan jangka panjang, menjalin komunikasi yang baik dengan nasabah, melibatkan organisasianggota dalam aktivitas pemasaran, mengembangkan budaya pelayanan untuk nasabah, dan memperoleh dan menggunakan informasi nasabah. Dari hasil penelitian hal ini, menunjukan bahwa nasabah merasa senang untuk bertransaksi di bank yang ada di kota Pekanbaru seperti simpanan dan pinjaman, karena terjadinya hubungan jalinan komunikasi yang baik antara karyawan dengan nasabah selama ini. Dapat dibuat saran bagi manajemen perbankan di kota Pekanbaru adalah sebagai berikut ini:

1. Disaran kepada manajemen perbankan di kota Pekanbaru agar tetap menjaga hubungan yang sudah terbina dengan baik selama ini kepada para nasabah dengan cara tetap memfokuskan komitmen karyawan yang dimiliki agar tetap memperhatikan dan meningkatkan jalinan komunikasi yang baik dengan nasabah didalam setiap transaksi yang dilakukan seperti simpanan, pinjaman, transfer dan jasa lainnya.

2. Disarankan kepada manajemen perbankan yang ada di kota Pekanbaru agar lebih meningkatkan lagi hubungan yang baik kepada nasabah untuk meningkat kepuasan nasabah dan membuat nasabah loyal sehingga nasabah akan terfokus untuk menjalin hubungan jangka panjang. Dengan pola hubungan yang lebih personal kepada nasabah, yang juga dilakukan bench marking secara periodik dengan pesaing terdekat.

3. Disarankan agar tetap memperhatikan setiap biaya transaksi yang menjadi konsekuensi dalam memanfaatkan jasa bank agar sepadan dengan layanan yang diterima nasabah dengan selalu mengadakan evaluasi secara kontinyu terhadap pricing biaya-bi- aya serta kualitas layanan kepada nasabah dengan selalu memperhatikan tingkat persaingan yang ada.

4. Disarankan agar lebih fokus dan komitmen dalam hal kecepatan dan keakuratan setiap transaksi yang ada agar memberikan makna yang penting bagi nasabah mengingat nasabah saat ini sangat heterogen dengan tingkat harapan yang semakin tinggi akan kepuasan layanan.

5. Disarankan agar tetap memperhatikan dan mengoptimalkan karaketristik keunikan produk dan layanan kepada nasabah agar tetap mempunyai nilai jual dan image yang tinggi dimata konsumen. Disisi lain langkah inovatif produk agar tetap selalu dikembangkan mengikuti keinginan dan keinginan nasabah, sehingga produk benar-benar tetap menjadi produk unggulan.

6. Perlu dilakukan evaluasi fungsi dari produk dan layanan yang lebih inovatif secara kontinyu, sehingga produk yang ada saat ini dimata nasabah mempunyai fungsi yang benar-benar berbeda dengan jasa dari bank lain dengan mempunyai keunggulan bersaing yang tinggi tetap terjaga.

7. Disarankan agar tetap meningkatkan rasa percaya nasabah terhadap produk dan pelayanan dengan tetap meningkatkan pelayanan, mengurangi tingkat complaint yang ada, sehingga tetap menjadi bank yang tumbuh sehat atas kepercayaan nasabah

8. Disarankan agar lebih meningkatkan jaminan atas layanan produk dan jasa oleh bank dengan melakukan langkah seperti selalu bersikap terbuka dan responsip atas saran dan kritk yang ada, kecepatan respon penyelesaian masalah dan lifetime service improvement.

\section{SIMPULAN}

Kesimpulan yang dapat diperoleh dari uraian di atas adalah sebagai berikut ini:

Dari tabel Model Summary dapat 
dilihat nilai $\mathrm{R}$ Square menunjukkan bahwa variabel-variabel customer relationship marketing mampu menjelaskan variabel nilai nasabah sebesar $54,4 \%$, sedangkan sisanya sebesar $45,6 \%$ dipengaruhi oleh variabel atau faktor yang ada diluar penelitian. Dimana nilai $\mathrm{R}=0,738$ artinya merupakan nilai kontribusi yang kuat dari variabel customer relationship marketing terhadap nilai nasabah yaitu sebesar $73,8 \%$.

Nilai signifikansi antara variabel-variabel customer relationship marketing terhadap variabel nilai nasabah secara simultan menunjukan nilai (value) sig. 0,000 $(<0,05)$ pada tingkat $\alpha=5 \%$. Hal ini menunjukan bahwa terdapat pengaruh yang signifikan antara variabel independent terhadap variabel dependent penelitian secara simultan. Nilai signifikan variabel customer relationship marketing terhadap variabel nilai nasabah secara parsial menunjukan nilai $<0,05$ pada tingkat $\alpha$ $=5 \%$. Dimana hal ini menunjukan bahwa terdapat pengaruh yang signifikan antara variabel independent terhadap variabel dependent penelitian secara parsial.

\section{DAFTAR RUJUKAN}

Band, William, A. 1991. Creating Value for Customers. John Wiley and Sons Inc.

Bennett, George. 1996. Relationship Formation and Governance in Consumer Markets: Transactional Analysis Versus The Behaviorist Approach. Journal of Marketing Management 12 (5): 417-436.

Blois, Keith J. 1996. Relationship Marketing in Organizational Markets: When is it Approriate?. Journal of Marketing Management 12: 161-173.

Butz, Howard E \& Goodstein, Leonard D. 1996. Marketing Customer Value: Gaining the Strategic Advantage.

Cadogan, John W. \& Diamantopoulus, Adamantios. 1995. The Market Orientation Construct: Integration and Internationalization. Journal of Strategic Marketing 3
(1): 41-60.

Christopher, Martin, Payne, Adrian, \& Ballantyne, David. 1991. Relationship Marketing : Bringing Quality, Customer Service, and Marketing Together. Butterworth Heinermann. Oxford : Boston.

Evans, Joel R and Laskin, Richard L. 1994. The Relationship Marketing Process: A Conceptualization and Application. Industrial Marketing Management 23. 439-452.

Gronroos, Christian. 1990. Relationship Approach to The Marketing Function in Service Contexts. Journal of Business Research 29 (1): 3-12.

Gronroos, Christian. 1994. The Marketing Strategy Containuum: Toward A marketing Concept for the 1990's. Management Decision 29 (1): 7-13.

Gummesson, Event. 1994. Marketing Relationship Marketing Operational. Service Industry Management 5 (5): 5-20.

Hughes, Arthur Middleton. 1999. Using Information to build and Maintain Relationship with Tour Customer. Relationship Marketing Reports. Vol III. Issue VIII. September.

Khoe, Yaou Tung. 1997. Relationship Marketing Strategi Kemampulabaan Jangka Panjang. Usahawan No.03. Th.XXVI. Maret.

Kohli, Ajay J., \& Jaworski, B.J. 1990. Market Orientation: The Contruct, Research Propositions, and Managerial Implications. Journal of Marketing 54:1-18.

Kotler, Philip dan Armstrong, Gary. 1997. Dasar-Dasar Pemasaran. Terjemahan. Prehallindo. Jakarta. 
Morgan, Robert M \& Hunt, Shelby D. 1994. The Commitment-Trust Theory of Relationship Marketing. Journal of Marketing 58 (3): 20-38.

Narver, John C., and Slater, Stanley F. 1990. The Effect of Market Orientation and Business Profitability. Journal of Marketing 54 (4): 20-35.

Palmer, Adrian. 1994. Relationship marketing. Back to Basics?. Journal of Marketing Management 10 (7): 571-581.

Prichard, Mark P., Havitz, Mark E., \& Howard, Dennis R. 1999. Analyzing the Commitment-Loyalty Link in Service Contexts. Journal of the Academy of Marketing Science 27 (3). p.333-348.

Sinkula, James M, William E. Baker \& Thomas Noordewier. 1997. A Framework for Market Based Organizational Leraning : Linking Values, Knowledge, and Behavior. Journal of the Academy of Marketing Science. Vol.25. no.4. p.305-318.

Sirohi, Niren, McLauglin, Edward $\mathrm{W}$ and Witink, Dick R. 1998. A Model of Consumer Perceptions and Store Loyalty Intentions for A Supermarket Retailer. Journal of Retailing 74 (2):223-245.

Stanton, William. 1978. Fundamental Of Marketing. Graw-Hill Book Company. Tokyo.

Stone, Merlin, Woodcock, Neil \& Wilson, Muriel. 1996. Managing The Change from marketing Planning to Customer relationship marketing. Long Range Planning 29 (5) : 675-683.

Swastha, Basu dan Irawan. 1997. Manajemen Pemasaran Modern. Liberty. Yogyakarta.

Too, Leanne H.Y, Souchon Anne L, and Thirkell Peter C. 2000. Relationship
Marketing and Customer Loyalty in A Retail Saetting: A Dyadic Exploration. Aston Bussines School Research Institute. June. pp. 1-36.

Woodruff, Robert B. 1997. Customer Value : The Next Source for Competitive Advantage. Journal of Academy of Marketing Science, Vol 25, no.2, p. 139-153. 